\title{
RESEARCH PAPER \\ Perceived quality in fresh peaches: an approach through structural equation modeling
}

\author{
Marcos Mora ${ }^{1}$, Jacqueline Espinoza ${ }^{2}$, Berta Schnettler ${ }^{3}$, Gemma \\ Echeverría $^{4}$, Stefano Predieri ${ }^{5}$, and Rodrigo Infante ${ }^{6}$ \\ 'Departamento de Economía Agraria, Universidad de Chile, Santa Rosa 11.315. La Pintana Santiago, Chile \\ ${ }^{2}$ Oficina de Estudios y Políticas Agrarias. Ministerio de Agricultura, Teatinos 40, Piso 8, Santiago, Chile. \\ ${ }^{3}$ Departamento de Producción Agropecuaria, Facultad de Ciencias Agropecuarias y Forestales. Universidad \\ de La Frontera. Casilla 54-D, Temuco, Chile. \\ ${ }^{4}$ Reserca i Tecnología Agroalimentariès (IRTA) Anàlisis sensorial i Estudis de consumidors. Av. Alcalde \\ Rovira Roure 191, E-25198 Lleida, España. \\ ${ }^{5}$ Istituto di Biometereologia (IBIMET). Consiglio Nazionale delle Ricerche (CNR) \\ Via Gobetti 101, I-40129 Bologna, Italy. \\ ${ }^{6}$ Departamento de Producción Agrícola, Universidad de Chile, Santa Rosa 11.315. La Pintana Santiago, Chile.
}

\begin{abstract}
M. Mora, J. Espinoza, B. Schnettler, G. Echeverría, S. Predieri, and R. Infante. 2011. Perceived quality in fresh peaches: an approach through structural equation modeling. Cien. Inv. Agr. 38(2): 179-190. The quality requirements that consumers consider in their decision to purchase fresh fruit have garnered a great deal of attention from the actors in the fresh fruit productivity chain. This study seeks to identify attributes that could explain how a consumer of fresh peaches perceives quality. The focus on the peach was because of the limited knowledge of the signs of quality that the consumer is seeking in this fruit. As a result, the objective was to produce a model that explains the perception of the quality of fresh peaches by Spanish consumers. A theoretical model was created that explains quality using a set of intrinsic and extrinsic attributes. The information was from a survey of closed questions administered in person to a non-probabilistic sample of 192 Spanish consumers. The methodology used was structural equation modeling, with an analysis for goodness of fit using the indicators CMIN/ DF, RMR, NFI, RFI, RMSEA, and HOELTER. Thus, by adjusting the values recommended by the literature, a model was identified that explains the quality decisions of the consumers studied using two sets of attributes: intrinsic and extrinsic. Finally, significant and strong relationships were established between the perceived quality and the homogeneity of the fruit and between the perceived quality and the availability in supermarkets and fruit stores.
\end{abstract}

Key words: Intrinsic and extrinsic attributes, quality, structural equation models.

\section{Introduction}

Understanding consumer perceptions of quality and how they are constructed to improve the connection between supply and demand

Received May 25, 2010. Accepted February 28, 2011.

Corresponding author:mmorag@uchile.cl has been a recurrent theme in the fruit industry over the past few years. For example, a study on apples by Harper et al. (2003) indicated that the facility with which consumers adapt to quality improvements has driven this industry to create new products and technologies, which means an increase in the expectations of apple quality. In this same context, the influence of the culti- 
var on consumer expectations of apple quality has been demonstrated by Jaeger and MacFie (2001). The quality of fruit and, in particular, of peaches has been commonly measured by physical and chemical properties that better explain maturation. Nevertheless, when speaking of quality from the consumer's perspective, these parameters only partially reflect what is considered to be good or poor quality. As a result, quality should be defined based on the requirements of the consumers and what they consider to be acceptable (Predieri et al., 2006). Those food and agriculture companies attempting to efficiently and profitably position themselves in the national and international markets necessarily require an understanding of consumer behavior and, in particular, the quality that consumers expect from a product (Mora et al., 2006). Because quality can be visualized, it can be explained through an objective component, objective quality, which is referred to as measurable and verifiable superiority with respect to a predetermined ideal standard, and through a subjective component, perceived quality, which is defined as a judgment by the consumer of the superiority or excellence of a product (Zeithaml, 1988). Similarly, Santesmases (2004) defines quality as a way to differentiate the product and also distinguishes between objective and subjective quality, with the first of these being measurable and verifiable, whereas the second is an evaluation by the consumer and is more important from the marketing point of view. In marketing, this subjective quality is called perceived quality (Verdú, 2001). Sulé (1998) posits that perceived quality is understood as "a global or multidimensional valuation made by the consumer of a product who imbues it with expectations based on certain attributes conditioning his choice, which will differ from the evaluation of another consumer, given the moment, the type of product and the consumer's sociodemographic profile". Also, if the product is understood as a device that generates a flow of services to the customer, Bitner et al. (1990) suggest that perceived quality derives from the encounter between the services provided and the customer, who then evaluates these and is satisfied or dissatisfied. It is generally accepted that a service of quality precedes customer satisfaction (Cronin and Taylor, 1992; Parasura- man et al., 1994; Caruana, 2002), and that the latter precedes customer loyalty (Bloemer and Kasper, 1995; Buttle, 1996; McDougall and Levesque, 2000; Caruana, 2002).

Elsewhere in the study of quality, one of the aspects on which several investigations have focused is the relationship that exists between quality and price. There are various points of view, ranging from those that suggest this relationship is direct (Wheatley et al., 1977; Phillips et al., 1983; Curry and Riesz, 1988) to those that indicate that this relationship is too wideranging and cannot be generalized (Bowbrick, 1982). Schnettler et al. (2007), in a study on food consumption conducted in Chile, determined that discounts ranging from 25 to $50 \%$ off of the normal price generate distrust in consumers because they associate it with inferior quality, especially for perishable goods. Tellis and Gaeth (1990) have proposed classifying consumers into three types: those that choose higher-priced products and who think that quality differences are associated with price; those that look for the best price-quality relationship and who optimize the decision based on complete information of existing products; and finally, a group that opts for low-priced products and does not believe that a higher price means better quality.

Moreover, some investigations have considered variables other than price as determinants of quality (Gardner, 1971 and Dodds et al., 1991), which has involved a more complex conceptualization of quality. Many studies refer to the relationship between brand and perceived quality, including comparing store brands with national brands (Bellizzi et al., 1981; Richardson et al., 1994; Davies and Brito, 2004).

The region of origin, expressed as the designation of origin, may have an interesting connection with quality for areas with a good reputation (Angulo and Gil, 2007). Bello and Calvo (2000), Bernués et al. (2003) and Verbeke and Ward (2006), however, all determined that origin does not significantly affect the perception of the quality of a product. Grunert (2005) further indicates that consumer knowledge of the origin of a product does not have any effect on 
the evaluation of the quality if the region of origin is unknown.

In light of this and to move towards a model of quality, Olson (1977) and Olson and Jacoby (1972) attempted an early dichotomization of the signs of quality into intrinsic and extrinsic attributes, which constitutes the conceptual framework of the model proposed in this investigation.

Intrinsic attributes can be defined as those that appear to be critical and without which a certain product would stop being what it is; they are properties or qualities that are derived from the physical composition of the good and that cannot be modified without causing alterations to its nature. Nelson (1970), referring to these types of attributes in consumer goods, distinguishes between those products whose quality can be determined prior to purchase (search goods) and those whose attributes can only be determined after the purchase or during consumption (experience goods). According to Kirmani and Rao (2000), the quality of experience goods is difficult to observe.

Extrinsic attributes, even when they present a more or less narrow relationship to the product, are those that are by definition outside the essence of the product (Olson and Jacovy, 1972). Zeithaml (1988), Verlegh and Steenkamp (1999), Huang et al. (2004), Amhed et al. (2004) and Chenga et al. (2007) consider, in whole or in part, the price, brand and advertising as extrinsic attributes, while mentioning as less relevant the guarantee, region of origin and others. For wine,
Verdú (2001) suggests that the attributes of experience and credibility for the non-expert public predominantly emphasize the importance of extrinsic attributes in the formation of the quality.

In the area of food and agriculture, some studies define perceived quality based on the intrinsic and extrinsic attributes, as in Sulé (1998) on fruit, Sanzo et al. (2003) on honey, Sulé et al. (2002) on fruit and Vázquez et al. (2002) on honey, all of which were developed with structural equation models, the methodology used in this investigation. In Sulé (1998) and Sulé et al. (2002), the intrinsic attributes influence the perceived quality of fruits more than do the extrinsic attributes; a similar situation arises in Sanzo et al. (2003) and Vázquez et al. (2002) on honey and Mora (2004) on wines from the denomination of origin of the Valencian Community, Spain. Finally, the primary objective of this investigation was to develop a model that explains the perception of the quality of fresh peaches among Spanish consumers and thus to contribute to solving the problem posed. Hence, the following hypothesis is suggested:

H1: The intrinsic and extrinsic attributes of fresh peaches contribute to explaining their perceived quality among Spanish consumers.

The conceptual model is an attempt to explain the perceived quality using the intrinsic and extrinsic attributes (Figure 1). Thus, the test model is composed of a set of observed variables (21), two first-order latent variables and one secondorder latent variable.

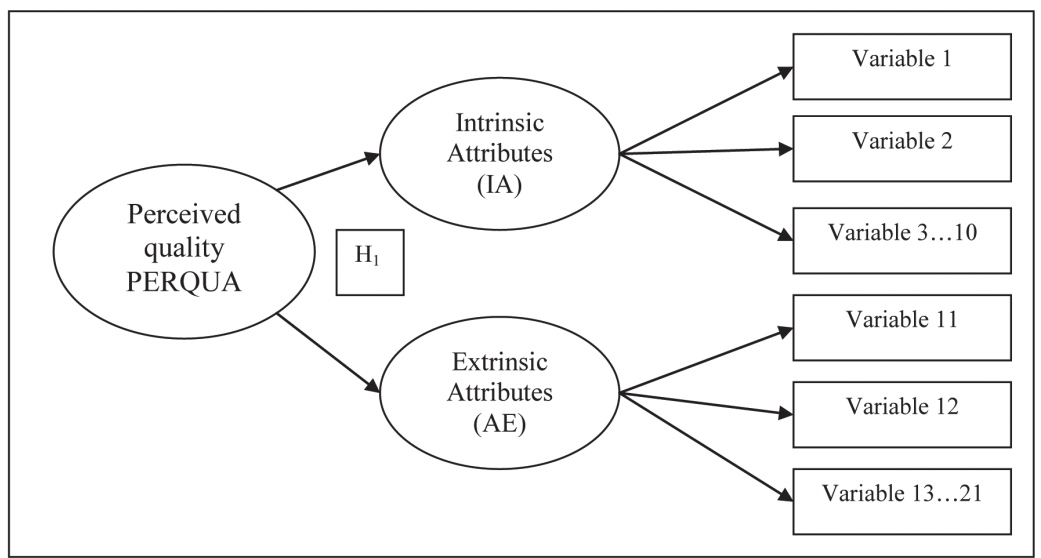

Figure 1. Conceptual model for the explanation of perceived quality among Spanish consumers of fresh peaches. 


\section{Materials and methods}

\section{Sample and questionnaire}

A survey administered to a non-probabilistic, convenience sample of consumers was used as the main source of information for this study (Halbrendt et al., 1995; Ness and Gerhardy, 1994). This instrument considered questions relevant to the population surveyed and consumer perceptions of the different attributes of peaches. Prior to the use of the questionnaire, a pretest was administered to 15 people. This survey was administered in person to 192 peach consumers in Lleida, Spain. The fieldwork was completed between December 2005 and January 2006. The profile of the people interviewed appears in Table 1. In this context, the sample used has two important features: the majority were women and most of people were highly educated. In their tropical fruit research, Sabbe et al. (2007) conclude that women have a greater degree of product knowledge. In addition, women remain primarily responsible for the purchase of food and also consume more fruit than men (Pollard et al., 2002). Moreover, there is empirical evidence suggesting that women are more interested in eating healthy and in deriving pleasure from eating (Roininen and Tuorila, 1999; Niva, 2006). The biasing of

Table 1. Socio-demographic profile of the polled sample.

\begin{tabular}{lcc}
\hline & Number & Percentage \\
\hline Male & Gender & \\
Female & 75 & 39.1 \\
Total & 117 & 60.9 \\
& 192 & 100.0 \\
From 18 to 24 & Age & \\
From 25 to 34 & 17 & 8.9 \\
From 35 to 49 & 65 & 33.9 \\
From 50 to 64 & 73 & 38.0 \\
Older than 64 & 34 & 17.7 \\
Total & 3 & 1.6 \\
& 192 & 100.0 \\
Elementary & 1 & \\
Secondary & 25 & 13.0 \\
Superior & 166 & 86.5 \\
Total & 192 & 100.0 \\
\hline
\end{tabular}

the sample toward the female gender was intended to collect primarily first-person information and to sample consumers with a certain level of familiarity with the product (Sabbe et al, 2009), which contributed to meeting the objectives of this research. In this sense, the consumer profile has been reported in the literature. Spawton (1991) uses the term "aspirational" to describe the linking of relative youth and higher socioeconomic levels. It is important to note that the sample was biased towards higher levels of education and relatively young age groups, under the assumption that the behavior of these strata spreads at some point across others, which would enable the approximation of future consumer behavior towards this type of fruit.

\section{Variables and measurement scales}

The variables used to model the perceived quality appear in Table 2. All of these were measured on a 5-level scale as follows:

1. I do not consider this attribute when evaluating the quality of peaches.

2. I do not frequently consider this attribute when evaluating the quality of peaches.

3. I consider this attribute $50 \%$ of the time when evaluating the quality of peaches.

4. I frequently consider this attribute when evaluating the quality of peaches.

5. I always consider this attribute when evaluating the quality of peaches.

Empirical evidence: construct of intrinsic attributes. Attributes such as color (Zeithaml, 1988), aroma (Mora, 2004), variety (Mora, 2004, Ruiz et al., 2004) and size (Sule et al., 2002) are considered intrinsic. In considering the attributes of the external appearance of the fruit and their homogeneity, even when there is no specific empirical evidence, the model developed by Sule et al. (2002) considers the form of the fruit to be an intrinsic attribute, which to a certain extent includes the attributes indicated.

Empirical evidence: construct of extrinsic attributes. Price is an extrinsic attribute as indicated in various studies (Zeithaml, 1988; Unwin, 1999; Horowitz and Lockshin, 2002; 
Table 2. Proposed variables for the development of a model of the perceived quality of fresh peaches among Spanish consumers.

\begin{tabular}{|c|c|c|c|c|c|c|c|}
\hline Intrinsic attributes & Code & Mean & $\begin{array}{c}\text { Typical } \\
\text { desviation }\end{array}$ & Extrinsic attributes & Code & Media & $\begin{array}{c}\text { Typical } \\
\text { desviation }\end{array}$ \\
\hline Intense color & ATRI1 & 3.35 & 1.32 & Price & ATRI11 & 3.13 & 1.20 \\
\hline Pale color & ATRI2 & 1.95 & 1.23 & Country of origin & ATRI12 & 2.88 & 1.66 \\
\hline Strong aroma & ATRI2 & 3.97 & 1.31 & Denomination of origin & ATRI13 & 2.31 & 1.37 \\
\hline Soft aroma & ATRI4 & 1.93 & 1.22 & Label & ATRI14 & 2.01 & 1.24 \\
\hline Peach variety & ATRI5 & 3.22 & 1.37 & Commercial brand & ATRI15 & 1.62 & 1.05 \\
\hline Fruit homogeneity & ATRI6 & 2.94 & 1.43 & Commercial premises & ATRI16 & 2.58 & 1.39 \\
\hline Big size & ATRI7 & 2.66 & 1.36 & Price-quality relationship & ATRI17 & 3.89 & 1.37 \\
\hline Small size & ATRI8 & 1.88 & 1.21 & $\begin{array}{l}\text { Availability } \\
\text { Supermarkets }\end{array}$ & ATRI18 & 2.46 & 1.45 \\
\hline Average size & ATRI9 & 3.19 & 1.38 & Availability in groceries & ATRI19 & 3.13 & 1.55 \\
\hline \multirow[t]{2}{*}{ External aspect } & ATRI10 & 4.12 & 1.20 & $\begin{array}{l}\text { Availability throughout } \\
\text { the year }\end{array}$ & ATRI20 & 1.74 & 1.14 \\
\hline & & & & Seller recommendations & ATRI21 & 2.64 & 1.40 \\
\hline
\end{tabular}

Mora, 2004). There is little empirical evidence regarding the availability in time and stores. However, in the study developed by Mora (2004), there are models of perceived quality for wines with the denomination of origin from the Valencian Community, Spain that include in-store availability as an extrinsic attribute. Sulé et al. (2002) considers points of sale as extrinsic attributes in his model of perceived quality for fruits. The trade name is also considered to be an extrinsic attribute by Zeithaml (1988). The sales force in the case of this study could be considered analogous to the recommendations of the salesperson as used by Sulé et al. (2002) as an extrinsic attribute to explain the perceived quality of fruit.

\section{Data analysis}

The information was analyzed using structural equation modeling (SEM), which is an extension of the multivariate techniques of multiple regression and factorial analysis (Hair et al., 1998), and which was applied to the theoretical framework presented in Figure 1. To develop the structural equation model, the contributions by Anderson and Gerbing (1988), Jöreskog and Sörbom (1996), Hair et al. (1999), Batista and Coenders (2000), Castro and Galindo (2000), Luque (2000) and Lévy and Varela (2003) were also considered, adjusting the following phases: 1 . Specification (presenting a model based on theory or application, constructing a path diagram and converting it into a set of structural equations), 2. Identification (assessing the identification of the model and making adjustments), 3. Estimation (selecting the type of matrix and determining parameters of the model), 4. Evaluation (model goodness of fit), 5. Interpretation and 6. Re-specification. The maximum probability method was chosen to perform this analysis (Jöreskog and Sörbom, 
1996). The AMOS 5.0 program was used (Arbuckle, 2003).

To establish indicators of the performance of the model, the $X^{2}$ test was used to evaluate the model; it depends on the sample size used (Bagozzi, 1981; Browne and Cudeck, 1993; Olsen, 2003), and our sample size was approximately 200, a size that, according to Boomsma (1982), is the minimum for the estimation of this indicator to be accurate. According to Batista and Coenders (2000), this indicator is considered acceptable when it is not significant $(\mathrm{P}>0.05)$, i.e., the restrictions imposed on the model are accepted and the data are fitted to it.

In addition, other indicators were used, as Bentler (1990) suggests. To evaluate the goodness of fit of the model, the following indicators were used: a) $X^{2} /$ d.f., an indicator which, according to Carmines and McIver (1981), is adequate if it presents a value less than 3 ; b) root mean square error of approximation (RMSEA), which is adequate if it presents values less than 0.08 (Browne and Cudeck, 1992); c) the goodness of fit index (GFI), for which Hoyle (1995) suggest that values over 0.9 are adequate; d) the comparative fit index (CFI) is adequate if it presents a value over 0.95 (Bentler, 1990); e) the adjusted goodness of fit index (AGFI), which measures the expected results in relationship to the observed data, with a value over 0.85 as adequate (Saba and Vasallo, 2002); f) the Hoelter Index, which was used to reinforce the overall fit provided by the GFI and AGFI indicators, with a value over 200 considered suitable for this indicator (Batista and Coenders, 2000); and finally, to evaluate the parsimony of the model with which the PRatio indicator was used, which must have values nearest to 1 .

\section{Results and discussion}

The model development involved two stages: the approximation of the model, which corresponds to a confirmatory factor analysis, and the structural equation analysis. This latter technique was used to establish the final coefficients and indicators to support the model obtained (Figure 1).

\section{Confirmatory factorial analysis (CFA) and validation of the measurement scales}

The initial model (CFA) considered 21 observed variables, with only 10 remaining at the end. Consequently, the model comprised 10 observed and 16 non-observed or latent variables. The model was identified by setting to 1 the regression coefficients of attribute 1 (ATRI1), with the latent variable intrinsic attribute (IA), of attribute 11 (ATRI11), with the latent variable extrinsic attributes (EA), and of latent variable (AI) with the second-order latent variable perceived quality of the peach (PERQUAL). In addition, the variances in the errors of the first-order latent variables (e26 and e27) were set at zero (Figure 2). The indicators of model performance were subsequently determined; the commonly used $X^{2} /$ d.f., CFI, GFI, RMSEA were used as reported in the literature (Hu and Bentler, 1998; Schumacker and Lomax, 1996; Olsen, 2003; Chen and Li, 2007) as well as the AGFI, the Hoelter Index and the PRatio. To evaluate the internal consistency and reliability of the scales, Cronbach's alpha was used, the values for the constructs of which are reported in Table 3. According to Nunnally (1967), an adequate value for this indicator is 0.70 ; other authors also report values near 0.7 for this indicator (Chen and Li, 2007). Sulé et al. (2002) report values over 0.61 for the different constructs that explain perceived quality in fruit products, which is similar to those obtained in this model with its two constructs. With regard to convergent validity, all the regression coefficients calculated are significantly different from zero $(\mathrm{P} \leq 0.001)$. The initial CFA had the following indicators: $X^{2}=83.052(\mathrm{P}<0.00)$, d.f. $\left.=35\right) X^{2} /$ d.f. $=2.373$, GFI $=0.914$, AGFI $=0.865, \mathrm{CFI}=0.899$, PRatio $=0.778$, RMSEA $=0.089$ and Hoelter $(\alpha=$ $0.05)=115$. Some of these indicators are outside the range suggested by the literature mentioned, for example, RMSEA and the Hoelter Index. As a result, the next step was to test the model, the results of which are presented below. 
Table 3. Observed and latent variables of first order and. internal reliability indicators and the convergent validity for the model of the perceived quality of fresh peaches among Spanish consumers

\begin{tabular}{|c|c|c|c|c|}
\hline $\begin{array}{l}\text { Constructs or } \\
\text { proposed latent } \\
\text { variables }\end{array}$ & Observed variables proposed & Code & Cronbach's $\alpha$ & $\begin{array}{c}\text { Critic Ratio/ incorporation } \\
\text { to the model }\end{array}$ \\
\hline \multirow[t]{11}{*}{$\begin{array}{l}\text { Intrinsic Attributes } \\
\text { (IA) }\end{array}$} & & & 0.67 & \\
\hline & Intense color & ATRI1 & & nd \\
\hline & Pale color & ATRI2 & & ni \\
\hline & Strong aroma & ATRI2 & & ni \\
\hline & Soft aroma & ATRI4 & & $5.203 * * *$ \\
\hline & Peach variety & ATRI5 & & $3.335^{* * *}$ \\
\hline & Fruit homogeneity & ATRI6 & & $6.762 * * *$ \\
\hline & Big size & ATRI7 & & $5.645^{* * *}$ \\
\hline & Small size & ATRI8 & & ni \\
\hline & Average size & ATRI9 & & ni \\
\hline & External aspect & ATRI10 & & ni \\
\hline \multirow[t]{12}{*}{$\begin{array}{l}\text { Extrinsic Attributes } \\
\text { (AEA) }\end{array}$} & & & 0.74 & \\
\hline & Price & ATRI11 & & nd \\
\hline & Country of origin & ATRI12 & & ni \\
\hline & Denomination of origin & ATRI13 & & ni \\
\hline & Label & ATRI14 & & ni \\
\hline & Commercial brand & ATRI15 & & $3.949 * * *$ \\
\hline & Commercial premises & ATRI16 & & ni \\
\hline & Price-quality relation & ATRI17 & & ni \\
\hline & Availability Supermarkets & ATRI18 & & $3.919 * * *$ \\
\hline & Availability in groceries & ATRI19 & & $3.999 * * *$ \\
\hline & Availability throughout the year & ATRI20 & & $\mathrm{ni}$ \\
\hline & Seller recommendations & ATRI21 & & $3.666^{* * *}$ \\
\hline
\end{tabular}

***Significant to 0.001 of the level of significance. nd: non-determined, due to the fact that its regression coefficient were fixed at 1 to identify the model. ni: non-incorporated to the model variable. 


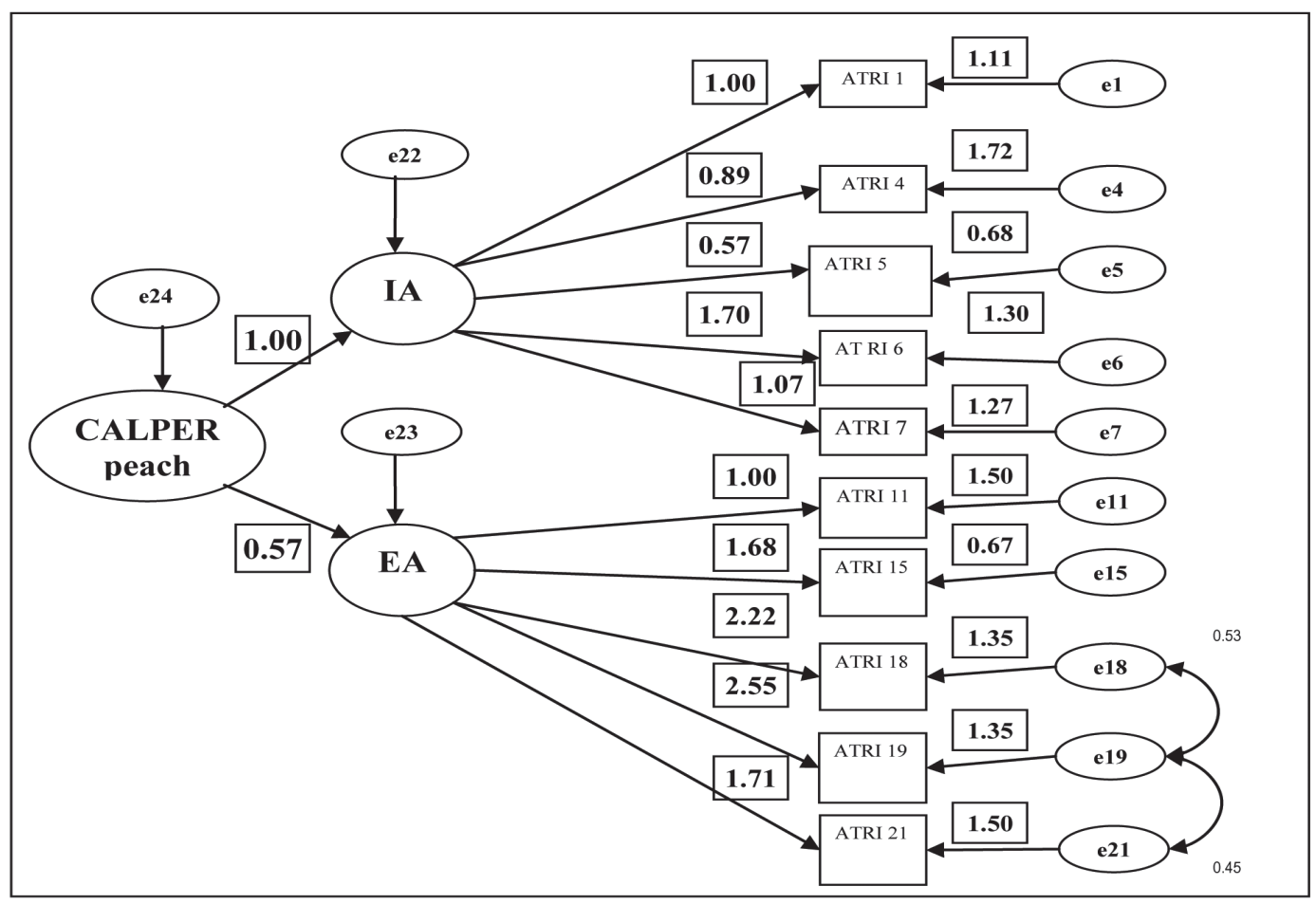

Figure 2. Structural equations model that explains the perceived quality of fresh peaches among Spanish consumers.

Stage 2: Assessment and re-specification of the structural equation model

To improve the performance of the model, correlations were established between e22 and e23 and between e 23 and e25, modifying the indices in accordance with the suggestion of Joreskog and Sorbom (1986). These changes enabled the identification of the definitive model, which had the following indicators: $X^{2}=38.437$ $(\mathrm{P}=0.237$, d.f. $=33), X^{2} /$ d.f. $=1.165$, GFI $=0.961$, AGFI $=0.935$, CFI $=0.989$, PRatio $=0.773$, RMSEA $=0.029$ and Hoelter $(\alpha=0.05)=236$. All of these were fitted as recommended in the literature. Hence, the perceived quality of fresh peaches could be explained by intrinsic and extrinsic attributes, which agrees with the results of Sulé (1998), Sulé et al. (2002) and Mora (2004). The regression coefficients used in the model were not standardized, because when they were standardized, the magnitude of the relationships obtained could not be clearly detected. Aroma has previously been considered as an intrinsic attribute (Verdú 2001 and 2003), as has the variety (Mora, 2004; Ruiz et al., 2004), as in this study. Moreover, in the model obtained, size helps to explain the perceived quality as an intrinsic attribute, as was similarly reported by Sulé et al. (2002). Color has been suggested by Zeithaml (1988) to be an intrinsic attribute, which is consistent with the model obtained in this study. As for the extrinsic attributes that explain perceived quality, it was determined that price fits in with this category, as noted in several studies (Zeithaml, 1988; Unwin, 1999; Horowitz and Lockshin, 2002; Mora, 2004). Similarly, it was proven that brand contributes to explaining perceived quality, as stated by Zeithaml (1988). In-store availability, considered in this model as an extrinsic attribute, is in agreement with what Mora (2004) has reported. Finally, the recommendation of the salesperson, incorporated into the model to explain perceived quality, was an extrinsic attribute here as in Sulé et al. (2002), who explain the quality perceived through an attribute called "sales force". Finally, previously it was suggested that between 4 and 7 attributes explain perceived quality (Sulé et al., 2002); yet in this investigation, this 
number is 10 , which may be explained by the differentiation strategies that companies use and the increasing levels of competitiveness they face, aspects that compel consumers to consider a greater number of variables in their processes of product assessment.

Based on these results, the proposed hypothesis is confirmed, i.e., it is possible to explain Spanish consumer perception of quality in fresh peaches using intrinsic and extrinsic attributes. In this respect, one result, which may be useful as a sign for the agents involved in this productivity chain, is the strong, significant and direct relationship between the homogeneity of the fruit and the intrinsic attributes and between the availability in fruit stores and supermarkets and the extrinsic attributes. Secondly, perceived quality is explained more robustly by the intrinsic than by the extrinsic attributes, which tallies with other food product studies that use this type of analysis.

Considering the characteristics of the regression coefficients obtained between the variables $\mathrm{AI}$ and AE and the observed variables ATRI6, ATRI19 and ATRI18, to develop marketing strategies in this fruit, we should emphasize the improvement of the homogeneity of peaches and their availability in the stores, fruit stores and supermarkets.
As a future line of investigation, it is suggested that new relationships that include the future changes in food demand be studied in greater depth. For example, every day the time available to shop decreases, which has triggered the creation of new marketing channels, such as electronic, where the extrinsic attributes are fundamental. Also, the consumer of the future, particularly in the developed and developing countries, will have greater economic resources and therefore will be more demanding in terms of food innocuousness, traceability, quality, marketing services and product differentiation, which will in turn give the food industry a greater dynamism than it currently has. For its part, supply will have to respond in a timely fashion, considering that modifications to intrinsic attributes that seemed impossible a few years ago are now possible thanks to advances in technology.

\section{Acknowledgements}

The authors wish to thank the Production Development Corporation (CORFO), part of the Chilean Ministry of Finance, for funding within the scope of the project: "Consolidation of the genetic improvement of the peach tree through the selection of varieties aimed at consumer satisfaction", Code PC04AT-11.

\section{Resumen}

M. Mora, J. Espinoza, B. Schnettler, G. Echeverría, S. Predieri y R. Infante. 2011. Calidad percibida en duraznos frescos: una aproximación a través de un modelo de ecuaciones estructurales Cien. Inv. Agr. 38(2): 179-190. Uno de los tópicos que más atrae la atención de los actores de la cadena productiva de fruta fresca, es entender los requerimientos de calidad que los consumidores de fruta fresca consideran en sus procesos de decisión de compra. En esta perspectiva, esta investigación se ha orientado hacia la identificación de relaciones significativas entre atributos que podrían explicar cómo percibe la calidad un consumidor de duraznos en estado fresco. Asimismo, se ha considerado focalizar el estudio en el durazno debido básicamente a que es una especie de la cual no se tiene conocimiento en términos de cuáles son los las señales de calidad que busca el consumidor cuando desarrolla sus preferencias. En virtud de lo señalado, el objetivo del presente es desarrollar un modelo que contribuya a explicar la calidad de duraznos frescos según la percepción de consumidores españoles. Para ello, se ha recurrido a un modelo teórico, el cual explica la calidad mediante un conjunto de atributos intrínsecos y extrínsecos. 
La fuente principal de información fue una encuesta de preguntas cerradas aplicada de forma presencial a una muestra no probabilística de 192 consumidores españoles. La metodología asociada al objetivo expuesto fue un análisis de ecuaciones estructurales, el cual fue sometido a un conjunto de indicadores de bondad de ajuste del modelo (CMIN/DF, RMR, NFI, RFI, RMSEA, HOELTER, entre otros). De tal modo, ajustándose a los valores recomendados por la literatura, se identificó un modelo que explica la calidad en los consumidores estudiados, mediante dos conjuntos de atributos: extrínsecos y extrínsecos. Finalmente, se determinaron relaciones significativas y altas, entre calidad percibida y homogeneidad de la fruta y, entre calidad percibida y disponibilidad en supermercados y fruterías.

Palabras clave: Atributos intrínsecos, atributos extrínsecos, calidad, modelos de ecuaciones estructurales.

\section{References}

Acebrón, L.B., and D.C. Dopico. 2000. The importance of intrinsic and extrinsic cues to expected and experienced quality: An empirical application to beef. Food Quality and Preference 11: 229-238.

Ahmed, Z., J. Johnson, X. Yang, C. Fatt, H. Teng, and L. Boon. 2004. Does country of origin matter for low-involvement products? International Marketing Review 21: 102-120.

Angulo, A.M., and J.M. Gil. 2007. Risk perception and consumer willingness to pay 7 for certified beef in Spain. Food Quality and Preference 18: 1106-1117.

Anderson, J.C., and D.W. Gerbing. 1988. Structural equation modelling in practice: a review and recomemmended two-step approach. Psychological Bulletin 103: 411-423.

Bagozzi, R. 1981. Evaluating structural equation models with unobservable variables and measurement error: a comment. Journal of Marketing Research 18: 375-381.

Batista J., and G. Coenders. 2000. Modelos de Ecuaciones Estructurales. Cuadernos de Estadística. Edit. La Muralla. Madrid, España. 176 pp.

Bellizzi, J.A., H.F. Krueckeberg, J.R. Hamilton, and W.S. Martín. 1981. Consumer perceptions of national, private and generic brands. Journal of Retailing 57: 56-70.

Bernués, A., A. Olaizola, and K. Corcoran. 2003. Extrinsic attributes of red meat as indicators of quality in Europe: An application for market segmentation. Food Quality and Preference 14: 265-276.
Bitner, M.J. 1990. Evaluating service encounters: the effects of physical surroundings and employee responses. Journal of Marketing, Chicago 54: 69-83.

Bloemer, J., and H. Kasper. 1995. The complex relationship between consumer satisfaction and brand loyalty. Journal of Economic Psychology 16: 311-329.

Bowbrick, P. 1982. Pseudos- research in marketing: The case of the price/perceived quality relationships. European Journal of Marketing 14: 466470.

Browne, M. W., and R. Cudeck. 1992. Alternative ways of assessing model fit. In: Bollen, K. A., and J. S. Long (eds.). Testing structural equation models Newbury Park, CA: Sage. p. 136-162.

Buttle, F., 1996. SERVQUAL: review, critique, research agenda. European Journal of Marketing 30: 8-35.

Carmines, E., and J. McIver. 1981. Analyzing models with unobserved variables: analysis of covariance structures. In: Bohrnstedt, G. W., and E. F. Borgatta (eds.). Social measurement - current issues. Beverly Hills: Sage Publications Inc. (65115) $254 \mathrm{pp}$.

Caruana, A. 2002. Service loyalty: the effects of service quality and the mediating role of customer satisfaction. European Journal of Marketing 36: 811-830.

Castro, J.A., and M. Galindo. 2000. Estadística multivariante: Análisis de correlaciones. Edit. Amarú Ediciones. Salamanca, España. 318 pp.

Chen, M.F., and H.L. Li. 2007. The consumer's attitude toward genetically modified foods in Taiwan. Food Quality and Preference 18: 662-674. 
Cronin Jr., J.J., and S.A. Taylor. 1992. Measuring service quality: a reexamination and extension. Journal of Marketing, Chicago 56: 55-69.

Curry D., and P. Riesz. 1988. Prices and price/quality relationships: a longitudinal analysis. Journal of Marketing 1:36-51.

Davies, G., and E. Brito. 2004. Price and quality competition between brand sand own brands: a value systems perspective. European Journal of Marketing 38: 30-55.

Dodds, W.B., K. Monroe, and D. Grewal. 1991. Effects of price, brand and stores information on buyers' products evaluation. Journal of Marketing Research 28: 307-319.

Gardner, D.M. 1971. Is there a generalized pricequality relationship? Journal of Marketing Research 8: 241-243.

Grunert, K. G. 2005. Food quality and safety: Consumer perception and demand. European Review of Agricultural Economics 32: 369-391.

Hair Jr., J.F., R.E. Anderson, R.L. Tatham, and W.C. Black. 1998. Multivariate Data Analysis. Prentice-Hall, Englewood Cliffs, NJ. 832 pp.

Haldbrent, C., F. Wirth, and G. Vaughn. 1991. Conjoint Analysis of the Mid- Atlantic Food - Fish Market for Farm Raised Hybrid Striped Bass. Southern Journal of Agricultural Economics 23: 55-163.

Hu, L., and P. Bentler. 1998. Fit indices in covariance structure modeling: sensitivity to under parameterized model misspecification. Psychological Methods 3: 424-453

Huang, W.Y., H. Schrank, and A.J. Dubinsky. 2004. Effect of brand name on consumers' risk perceptions of online shopping. Journal of Consumer Behavior 4: 40-50.

Jöreskog, K.G., and D. Sorbom. 1986. LISREL: analysis of linear structural relationships by the method of maximum likelihood, instrumental variables and least squares methods. Version VI. Moorseville, IN: Scientific Software.

Kirmani, A., and A.R. Rao. 2000. No pain, no gain: A critical review of the literature on signaling unobservable productc quality. Journal of Marketing 64: 66-79.

Lévy J.P., and J. Varela. 2003. Análisis Multivariante para las Ciencias Sociales. Edit. Pearson Prentice Hall. 870 pp.

Luque T., J. Ibañez, and S. Barrio. 2000. Consumer ethnocentrism measurement: an assessment of de reliability and validity of the CETSCALE in Spain. European Journal of Marketing 34:13531373.
McDougall, G.H.G., and T. Levesque. 2000. Customer satisfaction with services: putting perceived value into the equation. Journal of Services Marketing 14: 392-410.

Mora, M., J.A. Espinoza, and R. Miño. 2006. Segments determination of fresh peaches consumers through the Conjoint Analysis: An approximation to the Chilean market. Acta Horticulturae 713: 521-525.

Mora, M. 2004. Estudio de las actitudes y percepciones de los consumidores hacia los vinos de las denominaciones de origen de la comunidad Valenciana. Tesis Doctoral, Departamento de Economía Agroambiental, Ing. Cartográfica, Expresión Gráfica en la Ingeniería, Campus Orihuela, Sede Desamparados, Universidad Miguel Hernández. Elche, España. 286 pp.

Nelson, P. 1970. Information and consumer behavior. Journal of Political Economy 78:311-329.

Ness, M., and H. Gerhardy. 1994. Consumer preferences for quality and freshness attributes of eggs. British Food Journal 96: 26-34.

Niva, M. 2006. Can we predict who adopts healthpromoting foods? Users of functional foods in Finland. Scandinavian Journal of Food and $\mathrm{Nu}-$ trition 50: 13-24.

Nunnally, J. 1967. Psychometric theory. New York, NY. McGraw-Hill. 640 pp.

Olsen, S. 2003. Understanding the relationship between age and seafood consumption: the mediating role of attitude, health involvement and convenience. Food Quality and Preference 14:199-209

Olson, J. C., and J. Jacoby. 1972. Cue utilization in the quality perception process. In Proceedings of the Third Annual Conference of the Association for Consumer Research, ed. M. Venkatesan, Chicago: Association for Consumer Research, Chicago. p. 167-179.

Parasuraman, A., V. Zeithaml, and L.L. Berry. 1994. Reassessment of expectations as a comparison standard in measuring service quality: implications for further research. Journal of Marketing 58: $111-125$.

Phillips, L., D. Chang, and R. Buzzell. 1983. Product quality, cost position and business performance: a test of some key hypotheses. Journal of Marketing 2: 23-43.

Pollard, J., S.F. Kirk, and J.E. Cade. 2002. Factors affecting food choice in relation to fruit and vegetable intake: A review. Nutrition Research Reviews, 15: 373-387. 
Predieri, S., P. Ragazzini, and R. Rondelli. 2006. Sensory evaluation and peach fruit quality. Acta Horticulturae 713: 429-434.

Richardson, P.S., A. Dick, and A.K. Jain. 1994. Extrinsic and intrinsic cue effects on perception of store brand quality. Journal of Marketing 58: $28-36$.

Roininen, K., and H Tuorila. 1999. Health and taste attitudes in the prediction of use frequency and choice between less healthy and more healthy snacks. Food Quality and Preference 10: 357365.

Saba, A., and M. Vasallo. 2002. Consumer attitudes toward the use of gene technology in tomato production Food Quality and Preference 13: 13-21.

Sabbe, S., W. Verbeke, and P. Van Damme. 2007. Familiarity and purchasing intention of Belgian consumers for fresh and processed tropical fruit products. British Food Journal 110:805-818.

Sabbe S., W. Verbeke, and Van Damme, P. 2009. Perceived motives, barriers and role of labeling information on tropical fruit consumption: Exploratory Findings Journal of Food Products Marketing 15:119-138.

Santesmases, M. 2004. Marketing. Conceptos y Estrategias. Edit. Pirámide, S.A. Madrid. 1120 pp.

Sanzo, M. J., A.B. Del Río, V. Iglesias, and R. Vázquez. 2003. Attitude and Satisfaction in a Traditional Food Product. British Food Journal 105:771-790.

Schnettler, B., D. Ruíz, O. Sepúlveda, and N. Sepúlveda. 2008. Importance of the country of origin in food consumption in a developing country, Food Quality and Preference 19: 372382.

Schumacker, R., and R. Lomax. 1996. A beginner's guide to structural equation modeling. Ed. New Jersey: Lawrence Erlbaum. 186 pp.

Shewfelt, R.L. 1999. What is quality? Postharvest Biology and Technology 15: 197-200.

Spawton, T. 1991. Of wine and live asses: An introduction to the wine economy and state of wine marketing. European Journal of Wine Marketing 25: $1-48$.
Sulé, M. A. 1998. Calidad percibida: aplicación de los modelos de ecuaciones estructurales al ámbito agroalimentario. Tesis doctoral. Facultad de Economía y Empresa. Dpto. de Análisis Económico y Contabilidad. Universidad de Salamanca. Salamanca, España. 235 pp.

Sulé, M.A., J.P. Paquin, and J.P. Lévy. 2002. Modelling perceived quality in fruit products: their extrinsic and intrinsic attributes. Journal of Food Products Marketing 8: 29-48.

Tellis, G., and G.J. Gaeth. 1990. Best value, price seeking and price aversion: The impact of information and learning on consumer choices. Journal of Marketing 54: 34-45.

Vázquez, R., M. Sanzo, A. Del Río, and V. Iglesias. 2002. La actitud y el proceso de elección de compra: una aplicación en un producto de alimentación. Cuadernos Aragoneses de Economía 12: $15-46$.

Verbeke, W., and R.W. Ward. 2006. Consumer interest in information cues denoting quality, traceability and origin: An application of ordered probit models to beef labels. Food Quality and Preference 17: 453-467.

Verdú, A.J. 2001. Desarrollo y validación de una escala de medición de la calidad percibida del vino tinto. Comunicación presentada al XI Congreso Nacional de la Asociación Científica de Economía y Dirección de la Empresa (ACEDE). Zaragoza, España. Septiembre, 2001. 12 pp.

Verdú, A. J. 2003. Una escala multi-ítem para la medición de la calidad percibida en alimentos y bebidas. Revista Europea de Dirección y Economía de la Empresa 12: 59-76.

Verlegh, P., and J.B. Steenkamp. 1999. A review and meta analysis of countryof- origin research. Journal of Economic Psychology 20 (5): 521-546.

Wheatleay, J., and J. Chiu. 1977. The effects of price, store image, and product and respondents characteristic on perceptions of quality. Journal of Marketing Research 14:181-186.

Zeithaml, V.A. 1988. Consumers perceptions of price, quality and value: a means-end model and synthesis of evidence. Journal of Marketing 52: 2-22. 